\title{
Moisture Sorption Isotherm Characteristics of Ground Flaxseed
}

\author{
Ajit K Singh ${ }^{1 *}$ and Nibha Kumari ${ }^{2}$
}

${ }^{1}$ Department of Agricultural Engineering, NIMS University, Jaipur 303121, Rajasthan, India

${ }^{2}$ Pilot Plant Executive, Nestle R\&D Center India Pvt. Ltd., India

\begin{abstract}
Moisture sorption isotherm of ground flaxseed was determined at three different storage temperatures $\left(25^{\circ} \mathrm{C}, 35^{\circ} \mathrm{C}\right.$ and $\left.45^{\circ} \mathrm{C}\right)$ and relative humidity $(10-85 \%)$, using the standard static gravimetric method. The GAB, modified Henderson, modified Oswin and modified Halsey sorption model were tested to fit the experimental data. A nonlinear regression analysis method was used to evaluate the constants of four sorption equations. The modified Oswin and GAB model were found to be acceptable in predicting the moisture sorption isotherms of ground flaxseed.
\end{abstract}

Keywords: Ground flaxseed; Sorption isotherms; Relative humidity

\section{Introduction}

With increasing consumer interest in functional food, ground flaxseed is being used as an ingredient and a functional modifier in many foods. The seeds of flax or linseed (Linum usitatissimum L.) have been used for human consumption since ancient times. Flaxseed is recognized as nature's best vegetable source of Alpha-Linolenic Acid, a beneficial omega-3 fatty acid, which several studies indicate has the ability to reduce risk for a host of adverse health conditions. The prospective health benefits of oil seeds such as flaxseed, especially in relation to cancer and cardiovascular disease has got more consideration by the nutrition workers and food scientists.

Due to health promoting properties and excellent nutrient profile of flaxseed, it has been becoming a popular functional food product for incorporation in human diet. Flaxseed is being used extensively for the development of functional foods. The components of flaxseed, identified to exhibit the health benefits are fiber, lignans and linolenic acid (Omega-3 fatty acid). Moreover flaxseed is a good source of high quality protein, soluble fibers and phenolic compounds. Moisture sorption characteristics provide the necessary information regarding quality, stability and shelf life during packaging and storage of food powders. Hygroscopic nature of ground flaxseed causes for caking and follow deterioration by oxidation. The moisture content of the flour as a hygroscopic material exerts a strong influence on its quality and technological properties [1,2].

A moisture sorption isotherm explains the relationship between the water activity $\left(\mathrm{a}_{\mathrm{w}}\right)$ and the equilibrium moisture content for a food product at a constant pressure and temperature. The knowledge and understanding of moisture sorption isotherms for food products is of great importance in design and optimisation of processing as for instance in drying, for assessing packaging problems, for modelling moisture changes which occur during drying, for predicting shelf life stability, for ingredient mixing predictions etc. [3]. Representation of sorption data with best fit sorption model could be used as a tool for achieving these designs.

The objective of the present study was to determine the sorption isotherms of ground flaxseed over a range of temperatures $\left(25-45^{\circ} \mathrm{C}\right)$ and relative humidity (10-85\%). The specific objective includes the presentation of influence of temperature on sorption isotherm and analyzes the data with the help of four sorption isotherm equations available in the literature and finds the most suitable model describing the isotherm of ground flaxseed.

\section{Materials and Methods}

\section{Materials}

The material used to study the sorption characteristics was flaxseed for effective application in development of functional food that was procured from technology market, IIT Kharagpur. To be on safe side from the presence of cyanogenic glycosides, if any, the cleaned flaxseed was roasted until a nutty smell evolved. The roasting of flaxseed significantly reduces the cyanogenic glycosides content, thus making it fit for human consumption [4]. Flaxseed were cleaned, graded and roasted in a cast-iron skillet and stir the seeds in the skillet constantly until the seeds turn a uniform dark brown. This takes from 5 to 7 minutes (Figure 1). The roasted flaxseed was poured in a bowl and stir until cool. Finally roasted flaxseed is grounded in a spice grinder (Sumeet Research \& Holding Ltd., IS-4250, Madras, India).

\section{Experimental procedure}

The equilibrium moisture content was determined by standard gravimetric method by exposing the ground flaxseed to constant relative humidity environment created by saturated solution of a particular salt at three different temperatures, viz., 25,35 and $45^{\circ} \mathrm{C}$ [5]. Eight different salts viz., $\mathrm{NaOH}, \mathrm{CH}_{3} \mathrm{COOK}, \mathrm{MgCl}_{2}, \mathrm{~K}_{2} \mathrm{CO}_{3}, \mathrm{Mg}\left(\mathrm{NO}_{3}\right)_{2}$, $\mathrm{NaNO}_{3}, \mathrm{NaCl}$ and $\mathrm{KCl}$ were used to maintain respective water activity $\left(a_{\mathrm{w}}\right)$ inside separate vacuum desiccators in the range of 0.10 to 0.85 . Ground flaxseed was kept inside the desiccators for about 5-7 days for equilibration and final moisture content for each replicate was determined by oven drying method at $105^{\circ} \mathrm{C}$ for $24 \mathrm{hrs}$. Each set of experiment was repeated thrice and mean values were recorded.

\section{Fitting of EMC data to various sorption isotherm models}

Experimental data were fitted to four moisture sorption isotherm models, such as Guggenheim-Anderson-De Boer (GAB), modified Henderson, modified Oswin and modified Halsey models (Table 1),

*Corresponding author: Ajit K Singh, Assistant Professor, Department of Agricultural Engineering, NIMS University, Jaipur 303121, Rajasthan, India, Tel: 91 9799415000; E-mail: ajitksn@iitkgp.ac.in

Received February 27, 2014; Accepted March 25, 2014; Published April 03, 2014

Citation: Singh AK, Kumari N (2014) Moisture Sorption Isotherm Characteristics of Ground Flaxseed. J Food Process Technol 5: 319. doi:10.4172/2157-7110.1000319

Copyright: $\odot 2014$ Singh AK, et al. This is an open-access article distributed under the terms of the Creative Commons Attribution License, which permits unrestricted use, distribution, and reproduction in any medium, provided the original author and source are credited. 


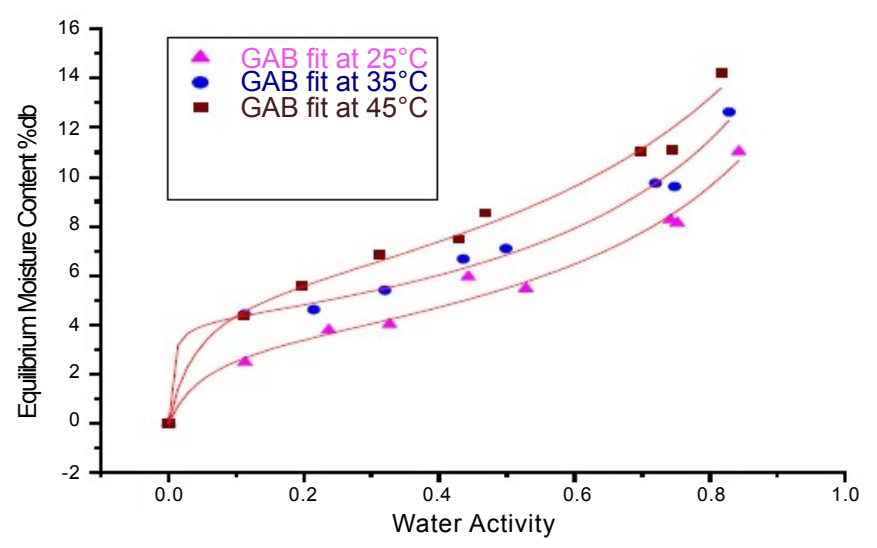

Figure 1: Sorption Isotherm of Ground Flaxseed at $25^{\circ} \mathrm{C}, 35^{\circ} \mathrm{C}$ and $45^{\circ} \mathrm{C}$

\begin{tabular}{|c|c|}
\hline Model & Mathematical Equation \\
\hline GAB & $M=\frac{A B C a_{w}}{\left[1-B a_{w}\right]\left[1-B a_{w}+B C a_{w}\right]}$ \\
\hline Modified Henderson & $1-a_{w}=\exp \left[-A(t+B) M^{c}\right]$ \\
\hline Modified Oswin & $M=(A+B t)\left(\frac{a_{w}}{1-a_{w}}\right)^{2}$ \\
\hline Modified Halsey & $a_{w}=\exp \left[\frac{-\exp (A+B t)}{M^{c}}\right]$ \\
\hline
\end{tabular}

Table 1: Mathematical models applied to the sorption isotherms to analyze EMC$\mathrm{a}_{\mathrm{w}}$ data for ground flaxseed.

where $a_{w}$ represents the equilibrium relative humidity in decimal; $M$ is the equilibrium moisture content in $\%(\mathrm{db})$; $\mathrm{t}$ is the temperature in ${ }^{\circ} \mathrm{C}$; $\mathrm{A}, \mathrm{B}, \mathrm{C}$ are sorption isotherm constants specific to each equation. Nonlinear regression analysis was used to calculate the respective constants using software like, Microsoft excel 2007 (Microsoft Office 2007, USA), Systat 8.0 (SPSS Science Marketing Department, SPSS Inc., 1998), and Origin 6.1 (Origin Lab Corporation, Northampton, MA 01060, USA, 2000).

\section{Goodness of fit to the sorption isotherm models}

Statistical validity of the fit to the models was evaluated using statistical parameters such as the root mean square error (RMSE) and from determination of co-efficient $\left(\mathrm{R}^{2}\right)$ and Mean Relative Error (MRE).

$$
\begin{aligned}
& \text { MRE }=\frac{100}{N} \sum\left|\frac{M_{e}-M_{P}}{M_{e}}\right| \\
& R^{2}=\frac{\sum\left(M_{e}-M_{p}\right)}{\sum M_{e}^{2} \sum M_{p}^{2}}
\end{aligned}
$$

Where $M_{e}$ is the experimental EMC value, $M_{p}$ is the predicted EMC value and $\mathrm{N}$ is the number of experimental data. The value of $\mathrm{R}^{2}$ close to 1 , and that of RMSE value close to 0 , indicate a better fit, MRE below $10 \%$ indicates a good fit for practical purposes [6].

\section{Results and Discussion}

\section{Effect of temperature and relative humidity on equilibrium moisture content}

The experimental results of ground flaxseed at each water activity $\left(a_{w}\right)$ for three temperatures are given in Table 2 for sorption isotherm. The equilibrium moisture content at each $\mathrm{a}_{\mathrm{w}}$ represents the mean value of three replications. The mean of the equilibrium moisture content of ground flaxseed ranged from 2.47 to $11.02,4.43$ to 12.63 and 4.35 to $14.21 \%(\mathrm{db})$ for the temperature of 25,35 and $45^{\circ} \mathrm{C}$ respectively in the relative humidity range of $10-85 \%$. The equilibrium moisture content increases with increase in temperature at constant relative humidity and increases with increase in relative humidity at constant temperature.

\section{Fitting of sorption models to experimental sorption data}

The results of nonlinear regression analysis of fitting the sorption equations to the experimental data are shown in Tables 3 and 4 . The coefficients of the modified GAB, modified Henderson, modified Halsey and modified Oswin models, their mean relative error (MRE), root mean square error (RMSE) and co-efficient of determination $\left(\mathrm{R}^{2}\right)$ were used to analyze the fitness of model. It is clear from this table that the modified Oswin model gives better fit to the experimental data with high $\mathrm{R}^{2}$ and lowest values of MRE and RMSE than other models.

Furthermore, quantitative evaluation of experimental sorption data provided on the basis of the GAB model is also good fit. Table 3 summarizes the estimated constants along with the mean relative error (MRE), root mean square error (RMSE) and co-efficient of determination $\left(\mathrm{R}^{2}\right)$. The low values of MRE (3.5122-6.0523), low value of RMSE (0.3291-0.4326) and correlation coefficients $\mathrm{R}^{2}(0.9843-0.9920)$ close to unity indicate that GAB model is good fit to the sorption data, and the estimated parameters were statistically acceptable.

\section{Conclusions}

The moisture sorption isotherm of ground flaxseed at different temperatures and water activities were determined by the standard gravimetric method using various saturated salt solutions. For ground flaxseed there was a significant effect of temperature on the equilibrium

\begin{tabular}{|c|c|c|c|c|c|c|}
\hline Salt & $25^{\circ} \mathrm{C}$ & & $35^{\circ} \mathrm{C}$ & & $45^{\circ} \mathrm{C}$ & \\
\hline & $\mathrm{a}_{\mathrm{w}}$ & $\mathrm{M}^{\mathrm{a}}$ & $\mathrm{a}_{\mathrm{w}}$ & $\mathrm{M}^{\mathrm{a}}$ & $\mathrm{a}_{\mathrm{w}}$ & $\mathrm{M}^{\mathrm{a}}$ \\
\hline $\mathbf{N a O H}$ & 0.113 & 2.47 & 0.112 & 4.43 & 0.111 & 4.35 \\
\hline $\mathbf{C H}_{3} \mathbf{C O O K}$ & 0.237 & 3.78 & 0.215 & 4.62 & 0.197 & 5.58 \\
\hline $\mathbf{M g C l}_{2}$ & 0.327 & 4.01 & 0.32 & 5.4 & 0.311 & 6.83 \\
\hline $\mathbf{K}_{2} \mathbf{C O}_{3}$ & 0.443 & 5.94 & 0.436 & 6.67 & 0.429 & 7.47 \\
\hline $\mathbf{M g}_{\mathbf{N O}} \mathbf{N O}_{2}$ & 0.528 & 5.47 & 0.499 & 7.09 & 0.469 & 8.54 \\
\hline $\mathbf{N a N O}_{3}$ & 0.742 & 8.24 & 0.72 & 9.75 & 0.699 & 11 \\
\hline $\mathbf{N a C l}$ & 0.752 & 8.12 & 0.748 & 9.61 & 0.745 & 11.1 \\
\hline $\mathbf{K C l}$ & 0.843 & 11 & 0.829 & 12.6 & 0.817 & 14.2 \\
\hline
\end{tabular}

Table 2: Equilibrium moisture content $M, \%$ d.b. of ground flaxseed obtained at different water activities and temperatures.

\begin{tabular}{|c|c|c|c|}
\hline GAB parameters & $\mathbf{2 5}^{\circ} \mathbf{C}$ & $\mathbf{3 5}^{\circ} \mathbf{C}$ & $\mathbf{4 5}^{\circ} \mathbf{C}$ \\
\hline MO & 3.496 & 4.112 & 5.623 \\
\hline $\mathbf{C}$ & 22.235 & 282.846 & 31.924 \\
\hline $\mathbf{K}$ & 0.8057 & 0.8036 & 0.7290 \\
\hline MRE (\%) & 6.0523 & 3.5122 & 3.6767 \\
\hline RMSE & 0.4186 & 0.3291 & 0.4326 \\
\hline $\mathbf{R}^{2}$ & 0.9894 & 0.9920 & 0.9843 \\
\hline
\end{tabular}

Table 3: Estimated parameters and comparison criteria for modified GAB model. 


\begin{tabular}{|c|c|c|}
\hline Models & Model Parameters & Values \\
\hline \multirow{8}{*}{ Modified Halsey } & A & 0.041 \\
\hline & B & 1.311 \\
\hline & C & 1.584 \\
\hline & MRE (\%) & 1.735 \\
\hline & RMSE & 5.374 \\
\hline & $\mathrm{R}^{2}$ & 0.970 \\
\hline & A & 0.815 \\
\hline & B & -11.499 \\
\hline \multirow{6}{*}{ Modified Henderson } & C & -1.664 \\
\hline & MRE (\%) & 3.667 \\
\hline & RMSE & 4.182 \\
\hline & $\mathrm{R}^{2}$ & 0.976 \\
\hline & A & 2.087 \\
\hline & B & 0.144 \\
\hline \multirow{4}{*}{ Modified Oswin } & C & 3.099 \\
\hline & MRE (\%) & 0.474 \\
\hline & RMSE & 0.669 \\
\hline & $\mathrm{R}^{2}$ & 0.995 \\
\hline
\end{tabular}

Table 4: Estimated parameters and comparison criteria for modified Halsey, Henderson and Oswin model.

moisture sorption in the range of temperatures studied. The equilibrium moisture content increased with increasing temperature at constant water activity. Among the sorption models chosen to test, modified Oswin and GAB model are suitable for describing the relationship between the equilibrium moisture content, water activity and temperature for ground flaxseed. The representation of sorption data with best fit sorption model can be used as a tool for achieving in design and optimization of processing as for instance in drying, for assessing packaging problems, for modeling moisture changes which occur during drying, for predicting shelf life stability, for ingredient mixing predictions.

\section{References}

1. Abdullah N, Nawawi A (2000) Fungal spoilage of starch based foods in relation to its water activity. Journal of Stored Products Research 36: 47-54.

2. Teunou E, Fitzpatrick JJ (1999) Effect of relative humidity and temperature on food powder flowability. Journal of Food Engineering 42: 109-116.

3. Spiess WEL, Wolf W (1983) The results of the COST 90 project on water acitvity. Physical properties of Foods. Applied Science Publishers, London.

4. Yang $\mathrm{H}$, Mao Z, Tan $\mathrm{H}$ (2004) Determination and removal methods of cyanogenic glycoside in flaxseed. Annual Int. Meeting, Ottawa, Ontario, Canada.

5. Labuza TP (1984) Moisture sorption: Practical aspects of isotherm measurement and use, American Association of Cereal Chemists. St Paul, Minnesota.

6. Lomauro CJ, Bakshi AS, Chen JY (1985) Evaluation of food moisture sorption isotherm equations Part 1: Fruit, vegetable and meat products. LebensmittelWissenschaft und-Technologie 18: 111-117. 